\title{
Effects of crystal size, acidity, and synthesis procedure on the catalytic performance of gallium and aluminum MFI zeolites in glycerol dehydration
}

\author{
Luiz H. Vieira ${ }^{\text {a }}$, Kele T.G. Carvalho ${ }^{b}$, Ernesto A. Urquieta-González ${ }^{c}$, Sandra H. Pulcinelli ${ }^{\text {, }}$, \\ Celso V. Santilli ${ }^{\mathrm{a}}$, Leandro Martins ${ }^{\mathrm{a}, *}$ \\ a Instituto de Química, UNESP - Univ. Estadual Paulista, Prof. Francisco Degni 55, CEP 14800-900, Araraquara, SP, Brazil \\ b Embrapa Instrumentação, Rua 15 de Novembro 1452, CEP 13560-970, São Carlos, SP, Brazil \\ c Centro de Pesquisas em Materiais Avançados e Energia - Universidade Federal de São Carlos, Rodovia Washington Luis, km 235, CEP 13565-905, São \\ Carlos, SP, Brazil
}

\section{A R T I C L E I N F O}

\section{Article history:}

Received 1 October 2015

Received in revised form

21 December 2015

Accepted 23 December 2015

Available online 29 December 2015

\section{Keywords:}

Glycerol dehydration

Acrolein

Aluminum- and gallium-MFI zeolites

Coke deactivation

\begin{abstract}
A B S T R A C T
The influence on gas-phase catalytic glycerol dehydration of crystal size (S: small, or L: large crystals), acidity, and synthesis procedure for isomorphous incorporation of gallium (Ga-S; Ga-L) or aluminum (Al-S; Al-L) in MFI zeolites was studied. The main product observed was acrolein, with the undesirable parallel formation of deactivating coke molecules such as polyglycols and polyaromatics. The Ga-S zeolite showed the best performance in this reaction, as it provided a combination of adequate accessibility to the microporous system and weak Brønsted acid sites. The chemical and structural properties of the fresh MFI zeolites were studied by X-ray diffraction, nitrogen sorption measurements, scanning electron microscopy, temperature-programmed desorption of $\mathrm{NH}_{3}, \mathrm{X}$-ray photoelectron spectroscopy, and ${ }^{27} \mathrm{Al}$ and ${ }^{29} \mathrm{Si}$ MAS-NMR. Solid-state ${ }^{13} \mathrm{C}$ MAS-NMR and thermogravimetric analyses of the spent MFI zeolites confirmed the differences in the nature and amounts of the carbonaceous deposits formed. The polyglycols were preferentially formed on the external surface of the zeolite crystals, as expected due to the greater exposed area. On the other hand, the polyaromatic compounds formed were more abundant inside the micropores of the MFI zeolites, especially those composed of larger crystals and with a greater number of strong Brønsted acid sites.
\end{abstract}

(c) 2015 Elsevier B.V. All rights reserved.

\section{Introduction}

Global warming caused by carbon dioxide emissions has led to a reduction in the use of fossil fuels as raw materials and consequently to changes in energy strategies. Biofuels have been proposed as substitutes for fossil fuels in order to reduce the impact of greenhouse gases. Due to political guidelines, the production of biodiesel has increased dramatically, resulting in large quantities of glycerol generated as a co-product of the transesterification of vegetable oils or animal fats. The transformation of glycerol into more valuable products, using reactions such as reforming, oxidation, hydrogenolysis, etherification, and dehydration, has been proposed as a way of enhancing the development of biorefineries [1].

\footnotetext{
* Corresponding author. Fax:+55 1633222308.

E-mail address: leandro@iq.unesp.br (L. Martins).
}

The intramolecular dehydration of glycerol to form acrolein is one of the most attractive procedures, because acrolein plays an important role as a precursor for the synthesis of central compounds, such as acrylic acid, used in the production of superabsorbent polymers and DL-methionine, a synthetic amino acid that is added to animal feed as a food supplement [2,3]. This reaction occurs on Brønsted acid sites via a two-step process that starts with the intramolecular dehydration of the internal hydroxyl groups of glycerol, followed by the terminal hydroxyl group, forming acrolein [4]. Strong or moderate Brønsted acid sites are more efficient for the production of acrolein. However, a negative aspect of these active sites is that not only the production of acrolein is favored, but also deactivating secondary reactions that lead to the deposition of nonvolatile carbonaceous compounds [5,6]. Therefore, weak Brønsted acid sites could provide an appropriate balance between acrolein selectivity and catalyst stability, leading to improved catalyst performance. 
Synthetic zeolites have many uses, including a wide range of applications as acid catalysts due to the unique combination of features such as Brønsted acidity and well-defined microporosity [7-10]. Among the various zeolites that have been discovered [11], the ZSM-5 zeolite (MFI structure) has been identified as an alternative catalyst for glycerol dehydration. Differences in Brønsted acid site concentrations induced by modification of the Si/Al molar ratio [12], as well as the influence of secondary pore families created by desilication [13], have been shown to have substantial effects on the deactivation by coke and the selectivity to acrolein.

Another important aspect that needs to be evaluated in terms of the performance of ZSM-5 zeolites as catalysts for glycerol transformation is the overall effect of the strength of Brønsted acid sites on conversion, selectivity, and catalyst stability. In the present work, two aspects of the synthesis of MFI zeolites were considered. The first was the synthesis of MFI structures containing gallium or aluminum atoms, in order to tune the strength of the Brønsted acid sites, based on the more basic nature of $\mathrm{Ga}^{3+}$, relative to $\mathrm{Al}^{3+}$. The substitution of aluminum heteroatoms by gallium decreases the interaction of the metal with the structural oxygen and consequently increases the interaction of oxygen with the proton of the H-MFI zeolite [14,15]. The second aspect was related to differences in the size of the MFI zeolite crystals (produced using different synthesis procedures), in order to show that this parameter influenced the mechanism of glycerol dehydration and the nature of the coke generated.

\section{Experimental section}

\subsection{Synthesis of MFI zeolites}

Two synthesis procedures, based on two silica sources (colloidal or alkoxide), were used with the aim of producing MFI zeolites with distinct characteristics.

The first procedure [16] resulted in large zeolite crystals, and the samples were denoted $\mathrm{Al}-\mathrm{L}$ and Ga-L (corresponding to Al-MFI and Ga-MFI, respectively). The following chemicals were used: deionized water, sodium aluminate $\left(\mathrm{NaAlO}_{2}\right.$, Sigma-Aldrich) or gallium nitrate (Sigma-Aldrich) as aluminum or gallium source, respectively, tetrapropylammonium bromide (TPABr, Sigma-Aldrich) as the organic structure-directing agent, ammonium hydroxide (29wt.\%, Quemis), and colloidal silica (40wt.\%, Sigma-Aldrich). The molar composition of the reaction mixtures corresponded to $50 \mathrm{SiO}_{2}: \mathrm{NaAlO}_{2}: 40 \mathrm{NH}_{4} \mathrm{OH}: 5 \mathrm{TPABr}: 667 \mathrm{H}_{2} \mathrm{O}$ for the Al-L sample, and $50 \mathrm{SiO}_{2}: \mathrm{Ga}\left(\mathrm{NO}_{3}\right)_{3}: 40 \mathrm{NH}_{4} \mathrm{OH}: 5 \mathrm{TPABr}$ : $667 \mathrm{H}_{2} \mathrm{O}$ for the $\mathrm{Ga}-\mathrm{L}$ sample. After $30 \mathrm{~min}$ under stirring, the homogeneous synthesis mixtures were transferred to stainless steel autoclaves and hydrothermally treated at $170^{\circ} \mathrm{C}$ during 5 days.

In the second procedure [17], which generated small zeolite crystals, the samples were denoted Al-S and Ga-S (corresponding to Al-MFI and Ga-MFI, respectively). The following chemicals were used: deionized water, aluminum nitrate or gallium nitrate (Sigma-Aldrich), tetrapropylammonium hydroxide, sodium hydroxide (Merck), and tetraethyl orthosilicate (TEOS, Sigma-Aldrich). The molar compositions of the reaction mixtures corresponded to 50TEOS: $\mathrm{Al}\left(\mathrm{NO}_{3}\right)_{3}: 0.16 \mathrm{NaOH}: 5 \mathrm{TPAOH}: 495 \mathrm{H}_{2} \mathrm{O}$ for the Al-S sample, and 50TEOS: $\mathrm{Ga}\left(\mathrm{NO}_{3}\right)_{3}: 0.16 \mathrm{NaOH}$ : 5TPAOH: $495 \mathrm{H}_{2} \mathrm{O}$ for the Ga-S sample. After $12 \mathrm{~h}$ under stirring, the homogeneous synthesis mixtures were transferred to stainless steel autoclaves and hydrothermally treated at $170^{\circ} \mathrm{C}$ during 1 day.

The solids obtained were recovered by washing with deionized water, followed by centrifugation, repeated three times. The catalysts were dried at $100^{\circ} \mathrm{C}$ during $6 \mathrm{~h}$, and the organic templates were removed by calcination during $8 \mathrm{~h}$ in a muffle furnace at $500{ }^{\circ} \mathrm{C}$ under an air atmosphere. The acidic forms of the catalysts were produced by three consecutive ion exchanges using a solution of $0.1 \mathrm{~mol} / \mathrm{L}$ ammonium nitrate, with washing and centrifugation after each ion exchange, and final calcination of the solids at $500^{\circ} \mathrm{C}$ during $2 \mathrm{~h}$ under an air atmosphere.

\subsection{MFI zeolites characterization}

The crystalline phases of the calcined samples were analyzed by X-ray diffraction using a Siemens D500 diffractometer, with $\mathrm{Cu}$ $K \alpha$ radiation selected by a curved graphite monochromator. Data were collected in a $2 \theta$ range from $3^{\circ}$ to $40^{\circ}$, using a step size of $0.01^{\circ}$ and a counting time of $1 \mathrm{~s}$. The unit cell parameters were calculated by the Rietveld refinement method, using PC-GSAS software with an EXPGUI graphical interface, where the parameters were refined based on the unit cell.

The zeolite crystal size was analyzed using a scanning electron microscope (Inspect F50, FEI). The samples were thinly deposited on an aluminum sample holder and then sputter-coated with a thin layer of conductive graphite.

The Si/Al and Si/Ga molar ratios were calculated using atomic absorption spectroscopy for the determination of aluminum atoms and flame emission spectroscopy for the determination of gallium atoms, employing a Varian 50AA spectrometer. Acid digestion was performed by suspending $100 \mathrm{mg}$ of sample in $1 \mathrm{~mL}$ of distilled water, followed by the addition of two drops $(\cong 0.1 \mathrm{~mL})$ of concentrated sulfuric acid and $1 \mathrm{~mL}$ of $40 \mathrm{wt} . \%$ hydrofluoric acid. This suspension was heated to $100^{\circ} \mathrm{C}$ during $2 \mathrm{~h}$, and the resulting white precipitate was diluted in $100 \mathrm{~mL}$ of deionized water.

Textural characterization of the solids was performed by nitrogen sorption measurements at liquid nitrogen temperature, with a relative pressure interval between 0.001 and 0.998 , using a Micromeritics ASAP 2010 instrument. Prior to the measurements, the samples were evacuated at $200^{\circ} \mathrm{C}$ during $12 \mathrm{~h}$. The micropore volumes of the samples were determined by the t-plot method [18].

The surface properties of the materials were evaluated by Xray photoelectron spectroscopy (XPS), using a UNI-SPECS UHV spectrometer. The $\mathrm{Mg} \mathrm{K} \alpha$ line $(1253.6 \mathrm{eV})$ was employed, and the analyzer pass energy was set to $10 \mathrm{eV}$. Deconvoluted spectra were obtained using multiple Voigt profiles, without placing constraints. The width at half maximum (FWHM) was varied between 1.5 and $2.2 \mathrm{eV}$, and the accuracy of the peak positions was $\pm 0.1 \mathrm{eV}$.

The strength of the acid sites and the total acidity of the MFI zeolites in the $\mathrm{H}$-form were determined by temperature programmed desorption of ammonia ( $\left.\mathrm{NH}_{3}-\mathrm{TPD}\right)$, using a Micromeritics AutoChem II 2920 apparatus. The samples were preheated to $600^{\circ} \mathrm{C}$ under a flow of He during $45 \mathrm{~min}$, and then cooled to $120^{\circ} \mathrm{C}$ for the $\mathrm{NH}_{3}$ adsorption. A stream containing 10 vol.\% $\mathrm{NH}_{3}$ in $\mathrm{He}(30 \mathrm{~mL} / \mathrm{min})$ was introduced during $30 \mathrm{~min}$ to achieve adsorption equilibrium. The excess and the physically adsorbed $\mathrm{NH}_{3}$ were then purged at $120^{\circ} \mathrm{C}$ under a flow of He during $60 \mathrm{~min}$. Finally, ammonia was desorbed in a $30 \mathrm{~mL} / \mathrm{min}$ flow of He, with heating from 120 to $600^{\circ} \mathrm{C}$ at a rate of $15^{\circ} \mathrm{C} / \mathrm{min}$. The ammonia desorption was monitored online by a thermal conductivity detector (TCD).

The Al-S and Al-L samples were characterized by solid-state ${ }^{27} \mathrm{Al}$ and ${ }^{29} \mathrm{Si}$ MAS-NMR to elucidate the differences in $\mathrm{Al}$ coordination between the samples synthesized using the different procedures. Spectra were recorded using a Varian INOVA 500 spectrometer equipped with a $4 \mathrm{~mm}$ probe, at a spinning rate of $14 \mathrm{kHz}$. The ${ }^{27} \mathrm{Al}$ chemical shifts were referenced to a $1.0 \mathrm{~mol} / \mathrm{L} \mathrm{Al}\left(\mathrm{NO}_{3}\right)_{3}$ aqueous solution. The experimental conditions were: operating frequency of $130.07 \mathrm{MHz}$, acquisition time of $0.0164 \mathrm{~ms}$, pulse width of $1.1 \mathrm{~ms}$, and recycle delay of $5 \mathrm{~s}$. For each ${ }^{27} \mathrm{Al}$ spectrum, 256 scans were acquired. The experimental conditions used for the ${ }^{29} \mathrm{Si} \mathrm{MAS}$ NMR (without cross polarization-CP) were: operating frequency of $79.49 \mathrm{MHz}$, acquisition time of $0.8192 \mathrm{~ms}$, pulse width of $3.4 \mathrm{~ms}$, and recycle delay of $700 \mathrm{~s}$. The ${ }^{29} \mathrm{Si}$ NMR CP/MAS experimental con- 

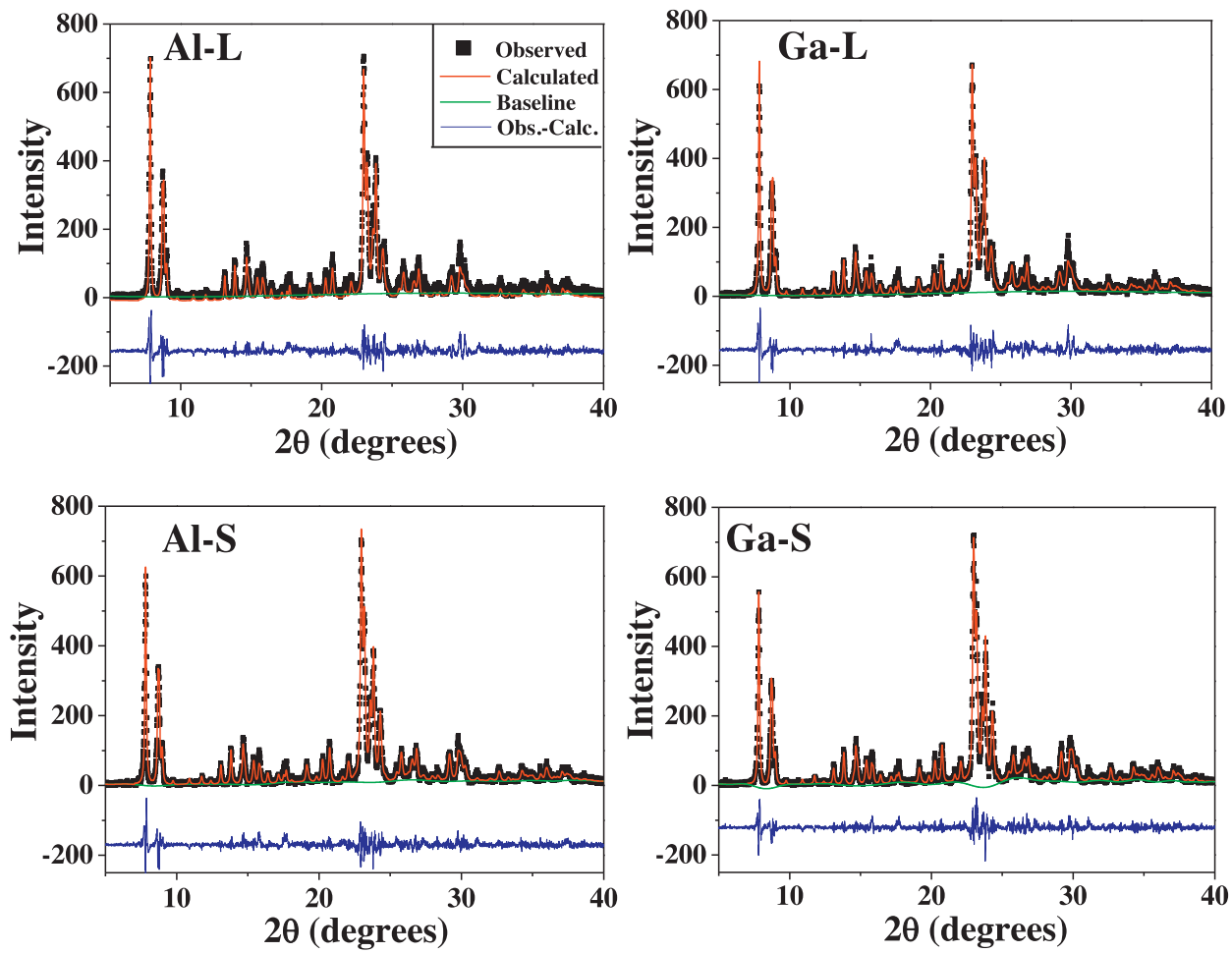

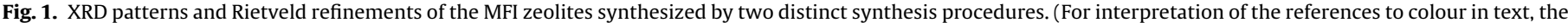
reader is referred to the web version of this article.).

ditions were: operating frequency of $79.49 \mathrm{MHz}$, acquisition time of $0.0449 \mathrm{~ms}$, pulse width of $3.8 \mathrm{~ms}$, and recycle delay of $5 \mathrm{~s}$.

Thermogravimetric analysis of the MFI zeolites after reaction (spent zeolites) was carried out under air $(100 \mathrm{~mL} / \mathrm{min})$ using a Netzsch thermobalance, with heating from 30 to $900{ }^{\circ} \mathrm{C}$ at a rate of $10^{\circ} \mathrm{C} / \mathrm{min}$.

Solid-state ${ }^{13} \mathrm{C}$ MAS-NMR spectra of the spent MFI zeolites were recorded using an Avance III $400 \mathrm{MHz}$ WB spectrometer (Bruker) equipped with a $4 \mathrm{~mm}$ probe and operated with a rotor-spinning rate of $15 \mathrm{kHz}$. The experimental conditions were: operating frequency of $12 \mathrm{kHz}$, pulse width of $2.4 \mu \mathrm{s}$, and contact time of $2000 \mu \mathrm{s}$. Before removing the spent catalysts from the reactor, they were flushed with a flow of nitrogen at $100 \mathrm{~mL} / \mathrm{min}$ during $30 \mathrm{~min}$ at $300^{\circ} \mathrm{C}$, in order to completely remove the chemisorbed volatile compounds or residues of glycerol, hence avoiding interferences in the NMR signals of the coked compounds.

The kinetic diameter $(\sigma)$ of glycerol was estimated using Eqs. (1) and (2), based on the critical point temperature, pressure and volume of glycerol [19]:

$\sigma=0.841\left(V_{\mathrm{C}}\right)^{1 / 3}$

$\sigma=2.44\left(\frac{T_{\mathrm{C}}}{P_{\mathrm{C}}}\right)^{1 / 3}$ where $V_{\mathrm{C}}$ is the critical volume (in $\mathrm{cm}^{3} \mathrm{~mol}^{-1}$ ), $T_{\mathrm{C}}$ is the critical Kelvin temperature, and $P_{C}$ is the critical pressure (in atmospheres). Critical point data were obtained from the Handbook of Chemistry and Physics [20]. The average of the two values was used as the glycerol kinetic diameter.

\subsection{Catalytic glycerol dehydration}

The catalytic glycerol dehydration was carried out in the gas phase at $300^{\circ} \mathrm{C}$ under atmospheric pressure in a continuous-flow glass fixed-bed reactor. Prior to the catalytic tests, $150 \mathrm{mg}$ of the acid MFI zeolite was heated to $300^{\circ} \mathrm{C}$ under a flow of nitrogen $(30 \mathrm{~mL} / \mathrm{min})$ and kept at this temperature during $15 \mathrm{~min}$. Glycerol was used as received ( $99 \mathrm{wt} . \%$, Sigma-Aldrich). The $10 \mathrm{wt} . \%$ glycerol solution in water was fed at $0.05 \mathrm{~mL} / \mathrm{min}$ using a positive displacement pump (KD Scientific), and nitrogen was used as the carrier gas $(30 \mathrm{~mL} / \mathrm{min})$. The resulting gas flow was fed into the reactor through a heated line. After reaction, the products and the unconverted reactant were collected in a gas-liquid separator maintained at $1{ }^{\circ} \mathrm{C}$ using an ultra-low refrigerated circulator. The collected liquid was analyzed using a Shimadzu GC-2014 gas chromatograph equipped with a flame ionization detector and a capillary column (Rtx-1, $30 \mathrm{~m}, 0.32 \mathrm{~mm}, 1 \mu \mathrm{m}$ ). Before each injection, a known mass

Table 1

$\mathrm{Si} /(\mathrm{Ga}$ or $\mathrm{Al})$ ratios, unit cell parameters calculated by Rietveld refinement, and particle sizes of the studied MFI zeolites.

\begin{tabular}{|c|c|c|c|c|c|c|c|}
\hline \multirow[t]{2}{*}{ Catalyst } & \multirow[t]{2}{*}{$\mathrm{Si} /(\mathrm{Ga}$ or $\mathrm{Al})$ ratio $^{\mathrm{a}}$} & \multirow[t]{2}{*}{$\mathrm{Si} /(\mathrm{Ga}$ or $\mathrm{Al})$ ratio $^{\mathrm{b}}$} & \multicolumn{3}{|c|}{ Unit cell parameters $(\AA ̊)$} & \multirow[t]{2}{*}{ Unit cell volume $\left(\AA^{3}\right)$} & \multirow[t]{2}{*}{ Particle size $(\mu \mathrm{m})$} \\
\hline & & & $\mathrm{a}$ & $b$ & $\mathrm{c}$ & & \\
\hline Al-L & 31 & 43 & 20.127 & 19.935 & 13.410 & 5380.81 & 10.0 \\
\hline Ga-L & 52 & 58 & 20.127 & 19.938 & 13.413 & 5382.42 & 12.0 \\
\hline Al-S & 27 & 18 & 20.121 & 19.904 & 13.395 & 5364.49 & 1.5 \\
\hline Ga-S & 55 & 11 & 20.126 & 19.908 & 13.398 & 5368.36 & 1.5 \\
\hline
\end{tabular}

a By chemical analysis.

b By X-ray photoelectron spectroscopy. 

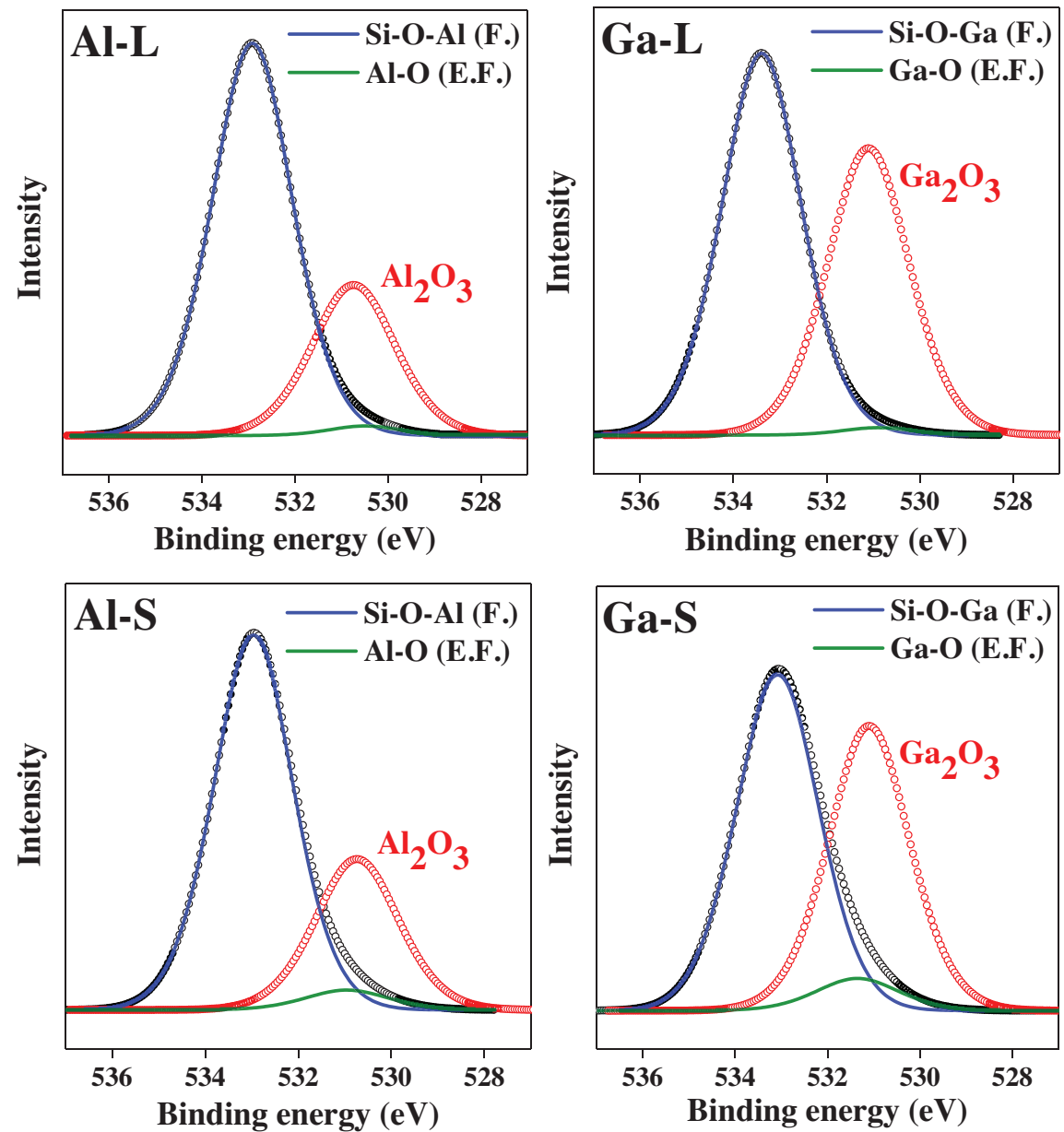

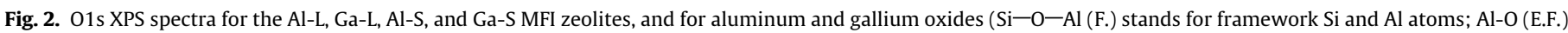
stands for extra-framework Al). (For interpretation of the references to colour in text, the reader is referred to the web version of this article.).

of $n$-butanol was added as an internal standard. The analyses were performed in triplicate, and the retention times were compared with those of authentic compounds. The glycerol conversion and products selectivity were calculated according to Eqs. (3) and (4), respectively.

$X_{\text {glycerol }}(\%)=\frac{n_{\mathrm{gl}}^{\text {input }}-n_{\mathrm{gl}}^{\text {output }}}{n_{\mathrm{gl}}^{\text {input }}} \times 100$

$S_{i}(\%)=\frac{n_{i}}{n_{\mathrm{gl}} \text { input }-n_{\mathrm{gl}} \text { output }} \times \frac{Z_{i}}{Z_{\mathrm{gl}}}$

where $n_{\mathrm{gl}}$ input and $n_{\mathrm{gl}}$ output are the molar flows of glycerol in the input and output ( $\mathrm{mol} / \mathrm{min}) ; n_{i}$ is the molar flow of product $i$; $Z_{\mathrm{gl}}$ and $Z_{i}$ represent the numbers of carbon atoms in the glycerol molecule and the products, respectively [21].

The glycerol conversion at time zero $\left(X_{0}\right)$ was estimated based on the fitted exponential decay according to Eq. (5), where $A$ is a catalytic activity decay constant.

$X_{\text {glycerol }}(\%)=X_{0} \times \exp (-t \times A)$

The relative deactivation $(D)$ of the MFI zeolites used in glycerol dehydration was calculated according to Eq. (6).

$D(\%)=\frac{\left(X_{\text {glycerol }}\right)_{\text {at time zero }}-\left(X_{\text {glycerol }}\right)_{\text {after } 6 \mathrm{~h}}}{\left(X_{\text {glycerol }}\right)_{\text {at time zero }}} \times 100$

\section{Results and discussion}

\subsection{Characteristics of the MFI zeolites}

The X-ray diffractograms (Fig. 1) confirmed that highly crystalline MFI structures were formed in the presence of either gallium or aluminum. The Rietveld refinements resulted in a satisfactory agreement between the calculated XRD patterns (red lines) and the experimental ones (black dots). No extra or displaced peaks were observed, and the standard deviations of the peak intensities (blue lines) were small. Gallium ions have an ionic radius of $0.047 \mathrm{~nm}$, while aluminum ions have an ionic radius of $0.039 \mathrm{~nm}$, so the $\mathrm{Ga}-\mathrm{O}$ bond length $(0.193 \mathrm{~nm})$ is greater than the $\mathrm{Al}-\mathrm{O}$ bond length $(0.175 \mathrm{~nm})$. Therefore, an increase in the unit cell volume should be an indication of the incorporation of gallium in the MFI structure, as observed here for the synthesized Ga-S and Ga-L MFI zeolites (Table 1).

The incorporation of $\mathrm{Ga}$ or $\mathrm{Al}$ in the zeolites resulted in dissimilar compositions: the $\mathrm{Si} / \mathrm{Ga}$ ratios for samples containing gallium were higher than the $\mathrm{Si} / \mathrm{Al}$ ratios for samples containing aluminum, with average values of 53 and 29, respectively. This could be explained by the slower kinetics of incorporation of gallium, due to differences in the $\mathrm{pH}$ values for maximum concentrations of the $\mathrm{Al}(\mathrm{OH})_{4}{ }^{-}$and $\mathrm{Ga}(\mathrm{OH})_{4}{ }^{-}$complex ions responsible for incorporation of the metals in the zeolite structure [15].

The samples were analyzed by XPS in order to obtain further information about the surface chemical composition. Fig. 2 compares the 01s spectra of the MFI zeolites with those of the cor- 
responding $\mathrm{Al}_{2} \mathrm{O}_{3}$ or $\mathrm{Ga}_{2} \mathrm{O}_{3}$ standards. Observation of the binding energies for the pure $\mathrm{Ga}$ and $\mathrm{Al}$ oxide standards (red lines at around $531 \mathrm{eV}$ in Fig. 2) revealed the existence of extra-framework oxides on the MFI zeolite surface, but at lower concentrations. Therefore, the results of XRD (showing unit cell expansion) and XPS (showing low concentrations of extra-framework $\mathrm{Al}_{2} \mathrm{O}_{3}$ or $\mathrm{Ga}_{2} \mathrm{O}_{3}$ on the external surfaces of the zeolite crystals) were in agreement and confirmed the isomorphic incorporation of gallium in the MFI structure [15].

Additional information could also be obtained from the XPS analysis. Visual comparison of the fitted component at around $531 \mathrm{eV}$ revealed small differences in the compositions of the samples. The surface chemical composition of the Al-S and Ga-S samples, determined by XPS, confirmed that the Si/Al and $\mathrm{Si} / \mathrm{Ga}$ molar ratios were different to those for the Al-L and Ga-L samples, due to the less intense formation of extra-framework $\mathrm{Al}_{2} \mathrm{O}_{3}$ or $\mathrm{Ga}_{2} \mathrm{O}_{3}$ in the S-samples, compared to the L-samples.

The scanning electron microscopy images (Fig. 3) showed that the crystal agglomerates of the Ga-L and Al-L zeolites had sizes of approximately $10 \mu \mathrm{m}$ in the longer direction, with irregular surfaces due to the intergrowth of small crystals. The Ga-S and Al-S zeolite crystals were around $1.5 \mu \mathrm{m}$ in size and had smooth surfaces. The differences in particle size must have been due to the dissimilar $\mathrm{H}_{2} \mathrm{O} / \mathrm{SiO}_{2}$ molar ratios used in the two synthesis procedures. This means that greater saturation of the Ga-S and Al-S reaction mixtures resulted in a higher rate of nucleation, relative to growth. It is also possible that the aging times employed for the Al$\mathrm{S}$ and Ga-S MFI zeolite synthesis mixtures could have contributed to the differences in crystal size.

The temperature programmed desorption of ammonia $\left(\mathrm{NH}_{3}-\right.$ TPD) results (Fig. 4 and Table 2) provided information about the strength and distribution of acid sites for the MFI zeolites and the aluminum and gallium oxides. In comparison with the $\mathrm{NH}_{3}-\mathrm{TPD}$

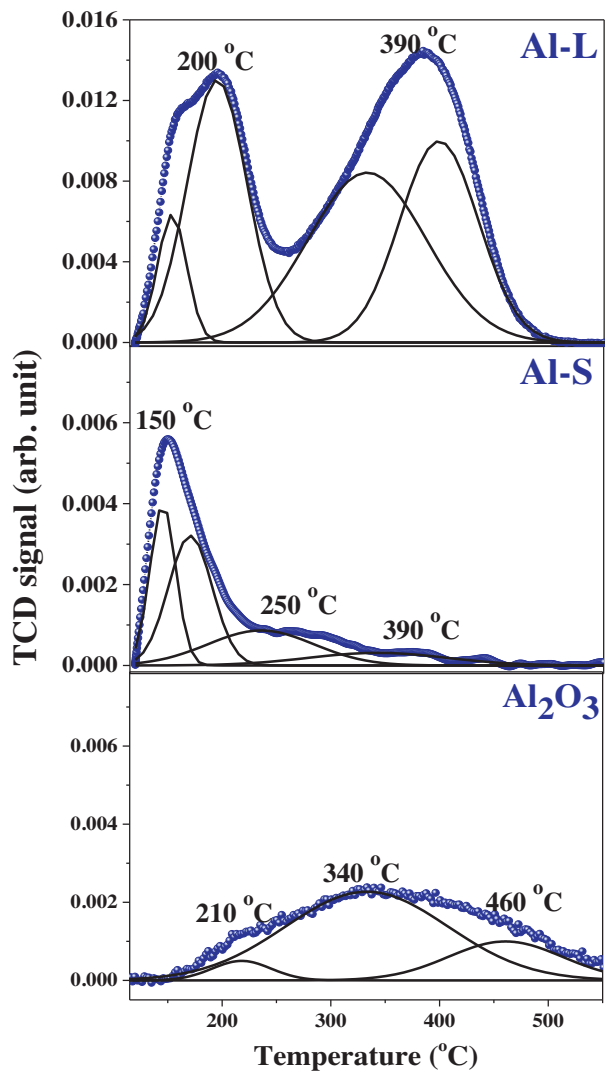

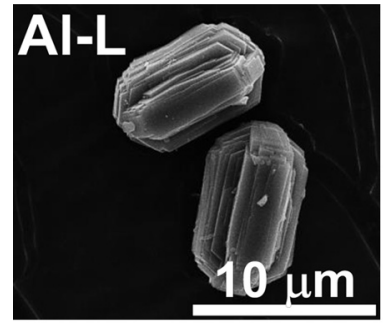
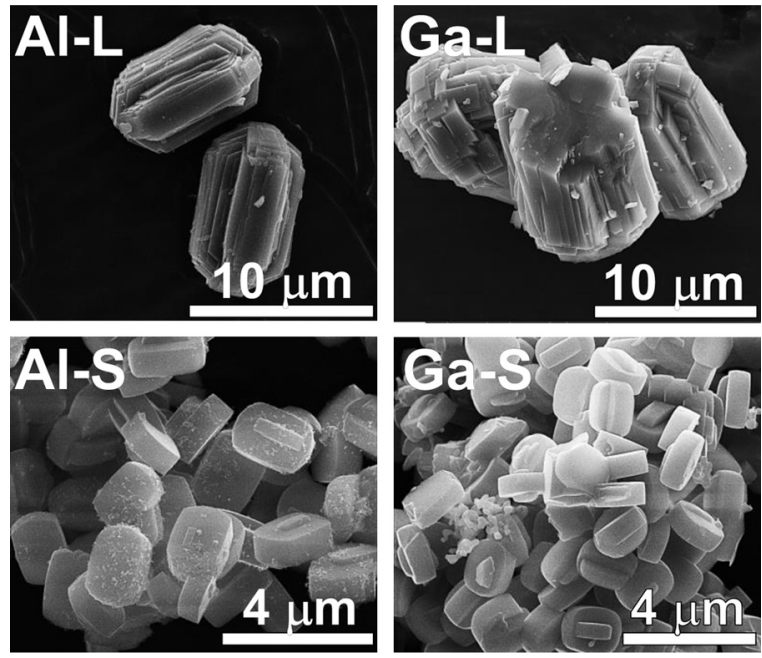

Fig. 3. Scanning electron microscopy images of the aluminum and gallium MFI zeolites.

profiles of the oxides, the Ga-L and Al-L MFI zeolites were more acidic and the distribution of their weak and moderate/strong acid sites, from $\mathrm{NH}_{3}$ adsorbed on $\mathrm{Si}-\mathrm{OH}-(\mathrm{Al}$ or $\mathrm{Ga}$ ), was clear and welldefined. The Ga-L sample showed a slight decrease in the strength of the acid sites, associated with a shift of the desorption peak to a lower temperature $\left(320^{\circ} \mathrm{C}\right)$, compared to the peak for the Al-L sample $\left(390^{\circ} \mathrm{C}\right)[22,23]$. This reflected the lower acidity of the acid sites generated by the gallium atoms present in the MFI structure, compared to those generated by the aluminum atoms [24]. On the other hand, the $\mathrm{NH}_{3}$-TPD profiles of the Ga-S and Al-S MFI zeolites (Fig. 4) showed very low amounts of desorbed ammonia in the

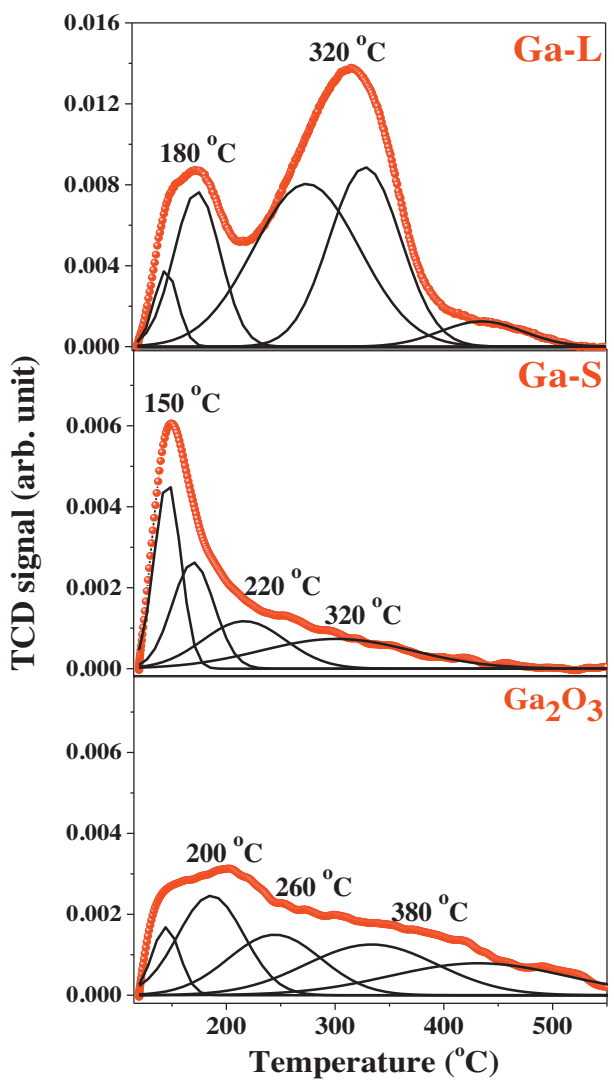

Fig. 4. Temperature-programmed desorption profiles of adsorbed ammonia for the Al-L, Ga-L, Al-S, and Ga-S MFI zeolites, and for aluminum and gallium oxides. 
Table 2

Acid properties of the studied MFI zeolites and aluminum and gallium oxides.

\begin{tabular}{lccll}
\hline Sample & $\begin{array}{l}\text { a Weak } \\
\left(\mu \mathrm{mol} \times \mathrm{g}^{-1}\right)\end{array}$ & $\begin{array}{l}{ }^{\mathrm{b}} \text { Medium } \\
\left(\mu \mathrm{mol} \times \mathrm{g}^{-1}\right)\end{array}$ & $\begin{array}{l}\text { CStrong } \\
\left(\mu \mathrm{mol} \times \mathrm{g}^{-1}\right)\end{array}$ & $\begin{array}{l}\text { Total } \\
\left(\mu \mathrm{mol} \times \mathrm{g}^{-1}\right)\end{array}$ \\
\hline $\mathrm{Al}-\mathrm{L}$ & 206.4 & 212.8 & 167.6 & 586.8 \\
$\mathrm{Al}-\mathrm{S}$ & 37.3 & 4.8 & - & 42.1 \\
$\mathrm{Ga}-\mathrm{L}$ & 100.7 & 337.1 & 23.6 & 461.3 \\
$\mathrm{Ga}-\mathrm{S}$ & 45.9 & 15.6 & - & 61.5 \\
$\mathrm{Ga}_{2} \mathrm{O}_{3}$ & 77.0 & 36.5 & 30.8 & 144.3 \\
$\mathrm{Al}_{2} \mathrm{O}_{3}$ & 8.1 & 30.7 & 20.2 & 59.0 \\
\hline
\end{tabular}

Acid sites strength:

a weak $\left(120-250^{\circ} \mathrm{C}\right)$.

b medium $\left(250-400^{\circ} \mathrm{C}\right)$.

c strong $\left(>400^{\circ} \mathrm{C}\right)$.

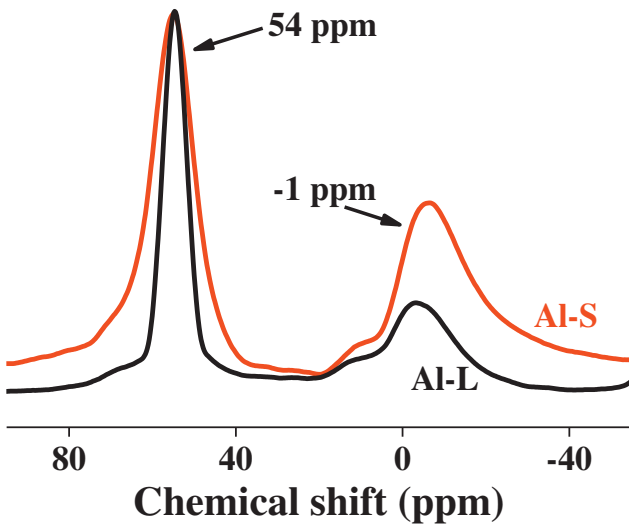

Fig. 5. ${ }^{27} \mathrm{Al}$ MAS-NMR spectra for the Al-L and Al-S MFI zeolites.

region of moderate and strong acid sites. This unexpectedly low acidity of these zeolites could have been due to the differences in incorporation of aluminum and gallium in the structures using the two different synthesis procedures [25].

In order to evaluate the possible structural causes of the marked difference in acidity, samples Al-S and Al-L were analyzed using solid-state ${ }^{27} \mathrm{Al}$ (Fig. 5) and ${ }^{29} \mathrm{Si}$ (Fig. 6) MAS-NMR. In the ${ }^{27} \mathrm{Al}$ MASNMR spectra, the single signal at around $54 \mathrm{ppm}$ corresponded to the tetrahedrally coordinated framework aluminum that was responsible for the generation of Brønsted acidity. This peak was present for both samples, but was broader in the Al-S sample spectrum, due to the contribution of tetrahedrally distorted Al species and the greater quantity of extra-framework aluminum species with chemical shifts around $-1 \mathrm{ppm}[12,13]$. The strength of the Brønsted acid sites in zeolites is governed by the tetrahedral coordination of heteroatoms in the crystalline framework. Therefore, the weak Brønsted acid sites in the Ga-S and Al-S samples were a consequence of the existence of $\mathrm{Ga}$ or $\mathrm{Al}$ in a defective environment.

The ${ }^{29} \mathrm{Si}$ NMR spectra show the results of measurements with and without cross polarization (CP and Non- $\mathrm{CP}$ ). The use of the two techniques enabled identification of the defective AlOH-silanol groups present in the samples. In the case of the Al-L sample, there was a very large difference between the Non-CP and CP/MAS spectra: the $\mathrm{Si}(0 \mathrm{Al})$ (Q4 sites) peak area decreased from $92 \%$ to $34 \%$, while the $\mathrm{Si}(1 \mathrm{Al})$ peak area (Q3 sites) increased significantly, indicating the presence of a large quantity of single silanol groups. For the Al-S sample, the $\mathrm{Si}(\mathrm{OAl})(\mathrm{Q} 4$ sites) peak area decreased from $100 \%$ to $13 \%$, and peaks corresponding to $\mathrm{Si}(1 \mathrm{Al})(\mathrm{Q} 3$ sites ) and $\mathrm{Si}(2 \mathrm{Al})$ (Q2 sites) appeared, with $53 \%$ and $34 \%$ of the total peak area, respectively, indicating a large quantity of single silanol Q3 sites and more defective terminal silanol groups (Q2 sites) [26,27]. The large amount of silanol groups observed in the Al-S sample could have been responsible for substantial structural defects, explaining the considerable difference between the acidities of the materials obtained using the two synthesis procedures.

\subsection{Glycerol dehydration: activity, selectivity, and deactivation}

The catalytic activity of the zeolites was studied for the glycerol dehydration reaction, which is extremely deactivating due to the deposition of non-volatile carbonaceous compounds on the catalyst surface. As expected, the conversions of glycerol on the MFI zeolites containing aluminum or gallium (Fig. 7) were different, due to their characteristic acidities resulting from the differences in the type and amount of metal and the synthesis procedure employed. In order to highlight the importance of the zeolite active sites in the conversion of glycerol, Fig. 7 also shows the conversion of glycerol on pure aluminum and gallium oxides. An initial comparison of the samples confirmed the importance of Brønsted acid sites in the MFI zeolites, in contrast to the Lewis acid sites of the metal oxides.

It was important to determine the conversion at time zero (Table 3), obtained by extrapolation of the curves presented in Fig. 7 , in order to exclude the effect of deactivation by coke in the interpretation of catalytic activity. In terms of glycerol conversion, the values ranged from 74 to $90 \%$. The samples counterparts containing aluminum were the highly active and comparing all samples the catalyst Al-S was the most active. Due to the high conversion used in the experiment, the comparison of the specific productivity of acrolein (in Table 3) was preferred instead of glycerol turnover frequency. Undoubtedly, comparing samples of same crystal size, the more acid Brønsted sites were more productive, however led to higher deactivation due to the formation of coke. The less acidic Brønsted acid sites of the gallium MFI zeolites were more important for glycerol conversion and stability (Table 3).

Considering the method of synthesis, the Al-S and Ga-S catalysts showed the best results, with better activity and lower deactivation due to a combination of two factors: (1) smaller amounts and lower strengths of their acid sites; (2) in the conversion of glycerol, the diffusion of reactants and products in the channels of the zeolites is hindered to such an extent that the reaction is controlled by the internal diffusion. Consequently, in the case of larger zeolite crystal aggregates, the more accessible active sites are located close to the surfaces of the crystallites. In terms of deactivation, large particles are affected to a greater extent, because blockage of the pore entrances renders the internal active sites inaccessible. The results were in agreement with these processes, since the external surfaces of the S-particle zeolites were 3-5 times larger, compared to the L-particle zeolites (Table 2).

In terms of the selectivity distribution (Fig. 8), the main product was acrolein, together with other products such as acetaldehyde, allyl alcohol, and propanal. Despite the improved stability of the gallium samples, the Al-MFI zeolites showed the best selectivity towards acrolein, evidencing the additive contribution of strong Brønsted acid sites for acrolein formation. There was a clear positive effect of Brønsted acid sites in enhancing the glycerol conversion to acrolein, compared to the Lewis sites of the pure oxides $\mathrm{Al}_{2} \mathrm{O}_{3}$ (only $4.0 \%$ selectivity) and $\mathrm{Ga}_{2} \mathrm{O}_{3}$ (4.5\%). However, despite this benefit, the catalysts with stronger active sites showed a greater decrease in the conversion of glycerol to acrolein, due to more severe coke deposition (Table 3 ) $[2,28]$. Other aspects of the catalytic reaction, such as the very low carbon balance (percentage of condensable chemicals - which includes non-converted glycerol and products in Fig. 8), selectivity of products below $50 \%$ for all the liquid compounds leaving the reactor, and the black appearance of the used catalysts, suggested that there was significant formation of coke, which negatively influenced the selectivity towards acrolein.

Based on the findings for glycerol conversion, the overall influence of the strength of the acid sites on the conversion to acrolein could be considered to follow the order: moderate/strong 

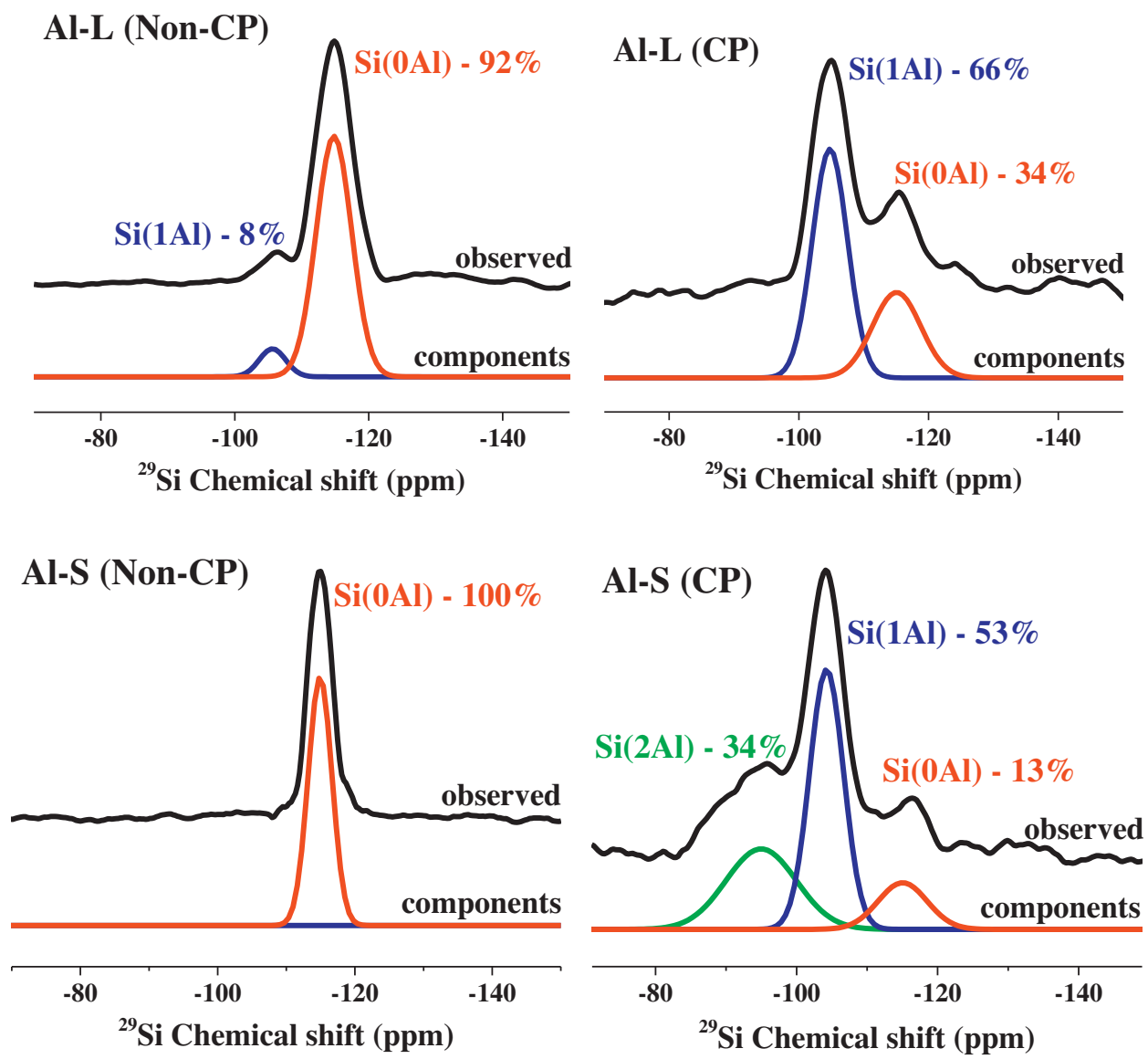

Fig. 6. ${ }^{29} \mathrm{Si}$ Non-CP and CP/MAS-NMR spectra for the Al-L and Al-S MFI zeolites.
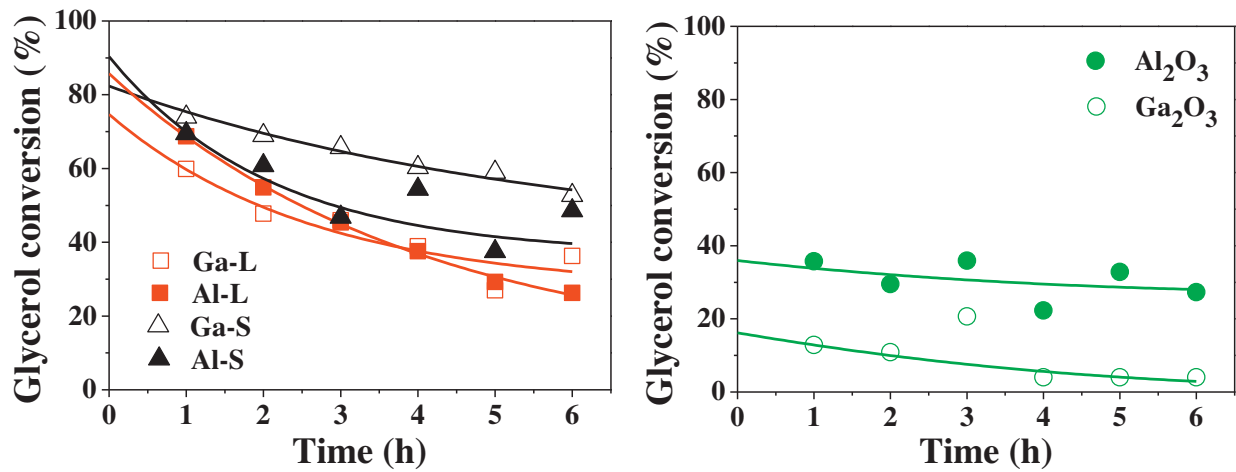

Fig. 7. Glycerol conversion at different reaction times on the Al-L, Al-S, Ga-L, and Ga-S MFI zeolites, and for aluminum and gallium oxides.

Table 3

Micropore volumes of the fresh and spent MFI zeolites, turnover frequencies at time zero (TOF $)$, deactivation during glycerol dehydration, and coke formed.

\begin{tabular}{|c|c|c|c|c|c|c|c|c|c|}
\hline \multirow[t]{2}{*}{ Catalyst } & \multirow[t]{2}{*}{$V_{\text {micro }} 0 \mathrm{~h}(\mathrm{~mL} / \mathrm{g})$} & \multirow[t]{2}{*}{$V_{\text {micro }} 6 \mathrm{~h}(\mathrm{~mL} / \mathrm{g})$} & \multirow[t]{2}{*}{$\begin{array}{l}\text { External surface } \\
\text { area }\left(\mathrm{m}^{2} / \mathrm{g}\right)\end{array}$} & \multirow[t]{2}{*}{$\begin{array}{l}\text { Conversion at } \\
\text { time } 0(\%)\end{array}$} & \multicolumn{2}{|c|}{$\begin{array}{l}\text { Specific } \\
\text { Productivity } \\
\left(\operatorname{mol}_{\mathrm{Acr} .} / \mathrm{mol}_{\mathrm{M}}{ }^{3+} . \mathrm{s}\right)\end{array}$} & \multirow[t]{2}{*}{$\begin{array}{l}\text { Deactivation } \\
\text { after } 6 \mathrm{~h}(\%)\end{array}$} & \multirow[t]{2}{*}{$\begin{array}{l}\text { Deactivation rate } \\
\text { constant }(\mathrm{A})\end{array}$} & \multirow[t]{2}{*}{$\begin{array}{l}\text { Coke amount } \\
\text { (g/g of catalyst) }\end{array}$} \\
\hline & & & & & After $1 \mathrm{~h}$ & After $6 \mathrm{~h}$ & & & \\
\hline Al-L & 0.30 & 0 & 3.0 & 85.6 & 0.81 & 0.26 & 70.4 & 77.3 & 0.09 \\
\hline Ga-L & 0.31 & 0 & 1.6 & 74.8 & 0.29 & 0.10 & 57.5 & 47.6 & 0.08 \\
\hline $\mathrm{Al}-\mathrm{S}$ & 0.32 & 0.10 & 9.5 & 90.2 & 0.77 & 0.23 & 56.5 & 53.7 & 0.04 \\
\hline Ga-S & 0.32 & 0.19 & 20.0 & 82.3 & 0.40 & 0.17 & 33.9 & 43.3 & 0.03 \\
\hline $\mathrm{Al}_{2} \mathrm{O}_{3}$ & - & - & - & 35.8 & - & - & 8.0 & $13.6^{a}$ & 0.03 \\
\hline $\mathrm{Ga}_{2} \mathrm{O}_{3}$ & - & - & - & 15.9 & - & - & 13.4 & $11.1^{\mathrm{a}}$ & 0.02 \\
\hline
\end{tabular}

a Despite of the low deactivation rate constant, samples $\mathrm{Ga}_{2} \mathrm{O}_{3}$ and $\mathrm{Al}_{2} \mathrm{O}_{3}$ had initial selectivity to acrolein of only around $10 \%$. 

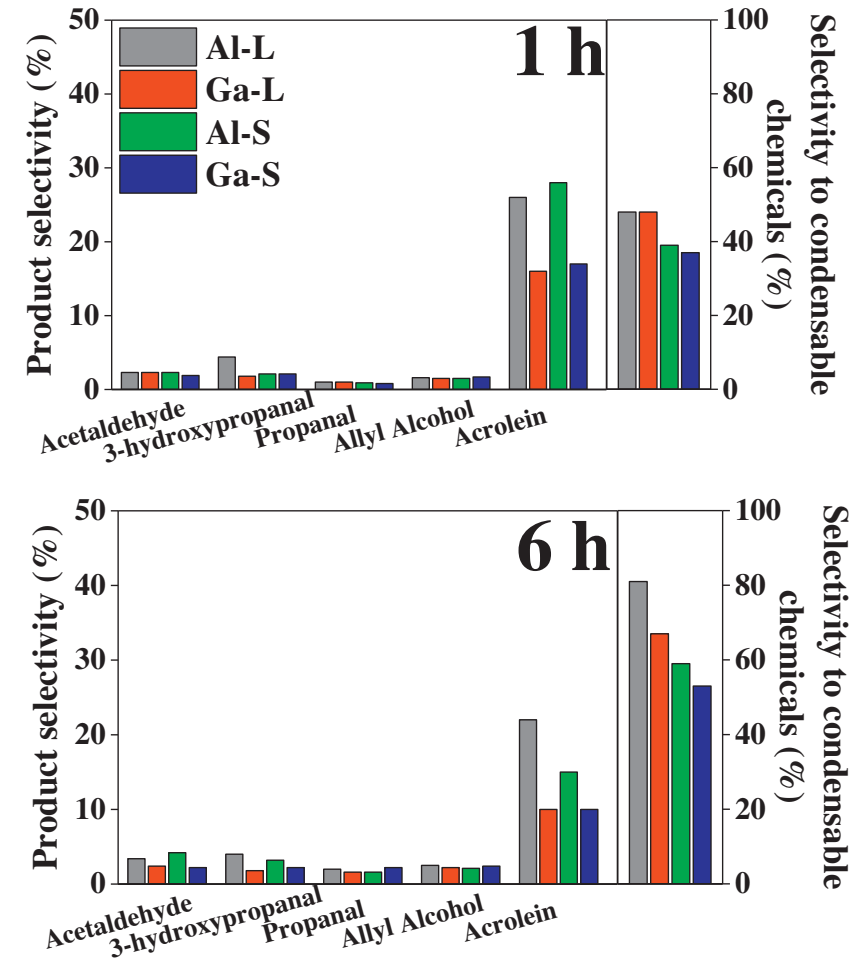

Fig. 8. Effect of reaction time on product selectivity and carbon balance after $1 \mathrm{~h}$ and $6 \mathrm{~h}$ on stream in the glycerol dehydration on the studied MFI zeolites.

Brønsted > weak Brønsted > Lewis. However, considering the overall effect of combined selectivity towards acrolein and the lower deactivation, the preferred acid sites followed the order: weak Brønsted $>$ moderate/strong Brønsted $>$ Lewis.

\subsection{Characteristics of coke compounds formed during glycerol dehydration}

Further insights into the deactivation of the MFI zeolites during glycerol dehydration were obtained by the quantification and characterization of coke compounds deposited on the spent MFI zeolites. In the thermogravimetric analysis of the samples after $6 \mathrm{~h}$ of reaction (Fig. 9), the decomposition of carbonaceous residues generated during glycerol dehydration occurred in the temperature range from 400 to $700^{\circ} \mathrm{C}$. Calculation of the coke percentages for the different samples (Table 3) showed that the Al-L and Ga-L catalysts contained greater quantities of coke, compared to the Al-S and Ga-S catalysts. This could have been due to the effect of diffusivity, because the larger zeolite particles possessed longer channels, resulting in greater residence times of glycerol and the products. In addition, polymerization and increased size of the less volatile carbonaceous residues was likely to prevent diffusion and lead to blocking of the zeolite pores [29].

The derivative curves of the samples (Fig. 9) revealed a small difference between the temperature peaks of the Al-L and Ga-L catalysts, indicating the formation of two types of compounds, which decomposed at 500 and $580{ }^{\circ} \mathrm{C}$ [30].

The differences in the deactivation behaviors of the Al-S, Al-L, Ga-S, and Ga-L catalysts were consistent with the findings of our previous work $[13,31,32]$, where it was found that several factors influenced coke deposition during glycerol transformation. These included the existence of secondary pores in the catalysts, density of the catalyst, strength and distribution of Brønsted or Lewis acid sites, and the use of co-catalysts to inhibit the propagation of coke on the catalyst surface.
In the work of Possato et al. [13], bimodal micro-mesoporous zeolites were prepared by desilication of purely microporous Al-MFI zeolites, resulting in changes in the location of coke molecules, which preferentially propagated in the intraparticle pockets. Despite substantial growth and retention of coke in the mesopores, the bimodal catalysts were much more active because most of the active sites located in the micropores were available and did not deactivate so rapidly due to coke deposition. In another study [31], the layered MWW family, including microporous MCM-22, pillared MCM-36, and delaminated ITQ-2, showed similar behavior in the gas-phase catalytic dehydration of glycerol. Although the characterization of acid sites revealed that the relationship between Brønsted and Lewis sites was not advantageous for glycerol conversion, these materials showed good performance in terms of the lifetime for catalytic conversion. Finally, we also used bifunctional $\mathrm{V}_{2} \mathrm{O}_{5} / \mathrm{MFI}$ catalysts for conversion of glycerol to acrolein and then to acrylic acid [32], where the catalyst lifetime was extended by a reduction in the amount of coke and changes in the families of deactivating carbonaceous compounds in the presence of $\mathrm{V}_{2} \mathrm{O}_{5}$. The $\mathrm{V}_{2} \mathrm{O}_{5} / \mathrm{MFI}$ catalysts were classified as multifunctional, because glycerol was double converted into acrylic acid, while at the same time the presence of vanadium oxides in the neighborhood of the acid sites inhibited the formation of coke monomers before they could oligomerize and block the active sites [32]. The vanadium oxide species acted as active redox sites and as a co-catalyst.

In the earlier works $[13,31,32]$ and in the present study, solidstate ${ }^{13} \mathrm{C}$ MAS-NMR spectroscopy enabled us to identify two families of coke that arose following the chemisorption of glycerol products or intermediates on the catalytic acid sites. These were bulky polycondensed polyglycol molecules and polyaromatics. The schematic outline presented in Fig. 10 illustrates the deactivation by deposition of coke on the catalysts and the distribution of these two families of compounds. Polyaromatics were more abundant inside the pores of zeolites, which could be explained by the similarity between the dimensions of the pore channels and the kinetic diameter of the glycerol molecule (5.4 $\AA$ ). On the other hand, polyglycols were more abundant on the external surface. Identical behavior has been observed for microporous MCM-22 and mesoporous MCM-36 and ITQ-2 [31].

The ${ }^{13} \mathrm{C}$ MAS-NMR spectra of the spent MFI zeolites (Fig. 11) revealed peaks at chemical shifts of 63,72 , and $77 \mathrm{ppm}$, related to intermolecular glycerol dehydration with production of polyglycol molecules, and peaks at $13,20,32$, and $130 \mathrm{ppm}$, due to the formation of polyaromatic compounds. The chemical shifts at 13 , 20 , and $32 \mathrm{ppm}$ were related to saturated carbon atoms of terminal chains bound to the oligomeric aromatic rings, which did not have time to cyclize and consequently increase the aromatic chain, due to interruption of the reaction [31-34].

Glycerol can undergo intramolecular reactions to form products of interest, such as acrolein [2], or polymerize via intermolecular reactions to form coke, as outlined in Fig. 12 [35]. The mechanistic pathway of polyglycol formation involves the activation of glycerol molecules on neighboring acid sites, followed by the successive coupling of hydroxyl groups of glycerol [31-34] by means of the transportation of bulky polycondensed molecules. The formation of polyglycols was observed in the Al-S and Ga-S catalysts, due to their greater external areas (Table 3), while in the other catalysts the coke mainly consisted of polyaromatics.

The reaction paths that resulted in the formation of polyaromatic compounds were favored in the entrance of the pore channels. In these reactions, an aromatic compound nucleus was formed and the transport of radicals to this nucleus resulted in an increase in the quantity of molecules that remained fixed inside the pores [33]. This type of coke is highly harmful for zeolites, because not only the active sites are covered, but the access to the micro- 

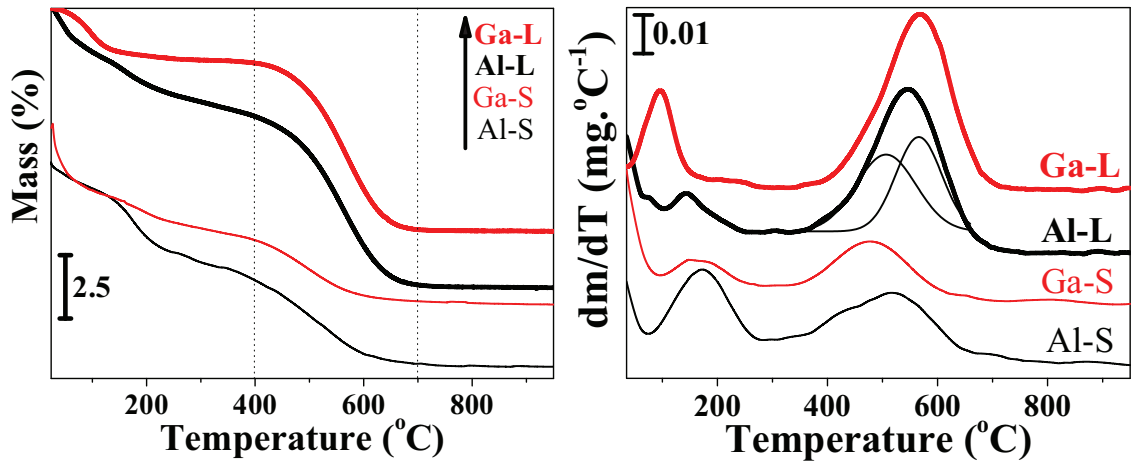

Fig. 9. Thermogravimetric profiles of the spent catalysts after $6 \mathrm{~h}$ on stream in the glycerol dehydration on the studied MFI zeolites.

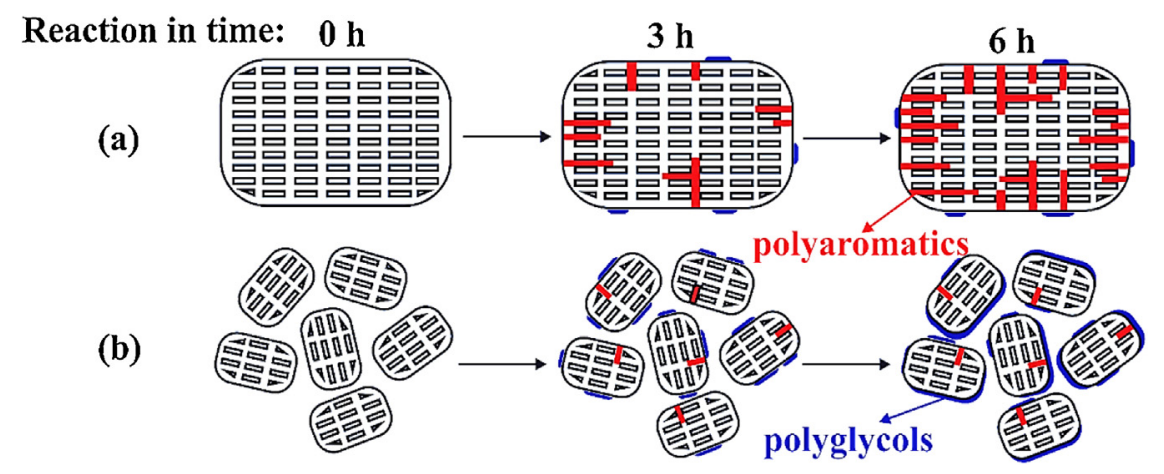

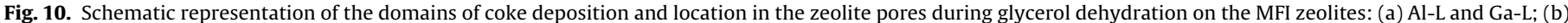
$\mathrm{Al}-\mathrm{S}$ and Ga-S.

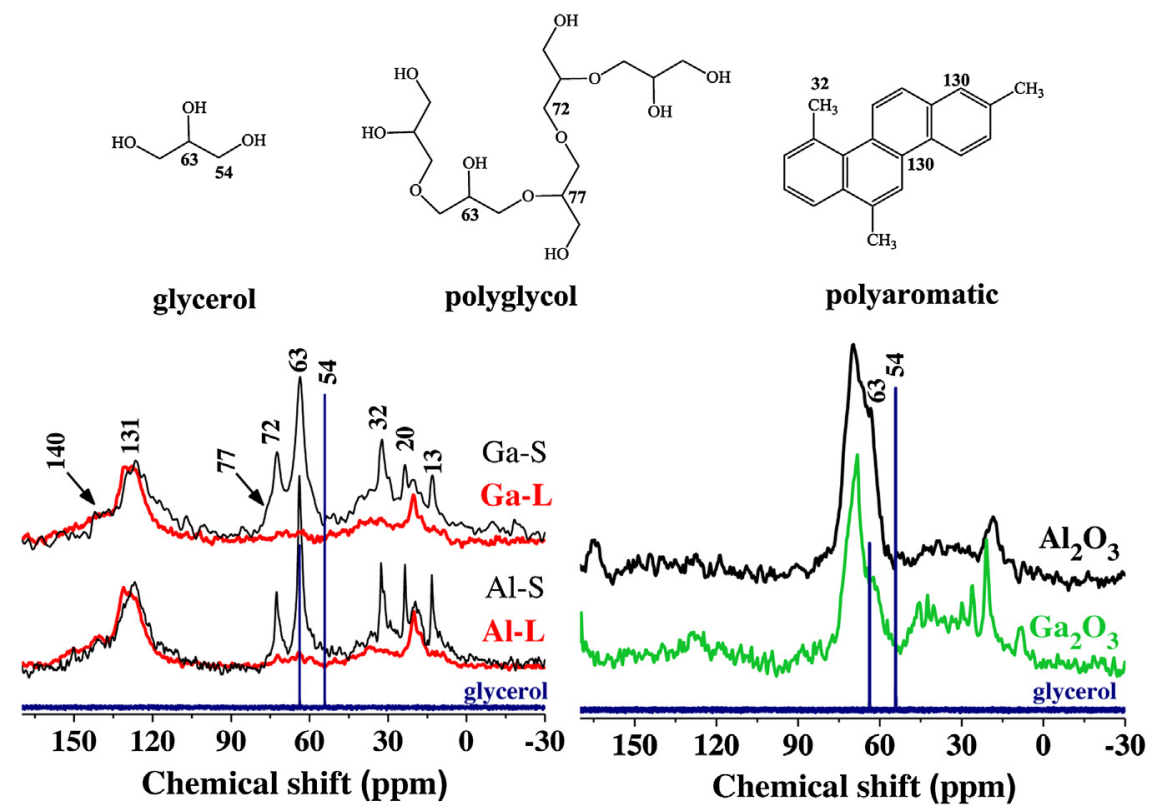

Fig. 11. ${ }^{13} \mathrm{C}$ NMR curves for spent Al-L, Al-S, Ga-L, and Ga-S MFI zeolites, and for aluminum and gallium oxides, after $6 \mathrm{~h}$ on stream in the glycerol dehydration.

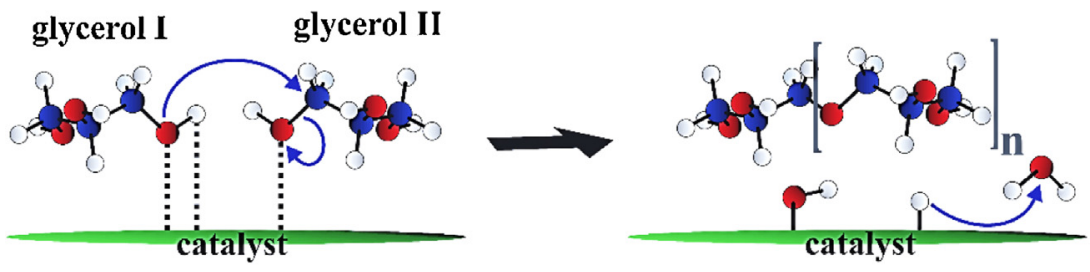

Fig. 12. Simplified reaction step during the glycerol dehydration leading to the formation of polyglycol compounds. 
pores are also blocked. Comparison of the weight percentages of the coked Al-L and Ga-L MFI zeolites showed that the less acidic nature of the samples containing gallium led to fewer polyaromatic compounds.

The solid-state $\mathrm{C}^{13}$ MAS-NMR spectra of the catalysts containing Lewis acid sites (the aluminum and gallium oxides) revealed the exclusive presence of polyglycols. This finding reinforces the antagonism created by the Brønsted acid sites: although they were important for the formation of acrolein from glycerol molecules, they promoted formation of the most deactivating polyaromatic compounds. A possible way to overcome this difficulty and obtain a zeolite catalyst with higher performance in glycerol transformation is to combine a suitable pore system with control of the balance of the strengths of the acid sites, together with the inclusion of a co-catalyst to oxidize the coke monomers formed [32].

\section{Conclusions}

All the gallium and aluminum MFI zeolites studied were highly active in the glycerol dehydration reaction. The main product was acrolein, with undesirable parallel formation of deactivating coke molecules such as polyglycols and polyaromatics. The Ga-S zeolite presented the best performance in this reaction, as reflected by the selectivity towards acrolein and longer catalytic stability, due to the combination of adequate accessibility to the microporous system and weak Brønsted acid sites. In addition to differences in the strength of the Brønsted acid sites, the size of the zeolite crystals affected the nature of the coke molecules deposited on the catalysts. Polyglycol molecules were preferentially formed at the external surfaces of small zeolite particles, as expected due to the greater area exposed, while polyaromatic compounds were mainly formed within the entrance of zeolite micropores and on the more acidic aluminum-containing MFI zeolites. The formation of polyaromatics was supported by the mechanistic steps involving the transport of radicals to internally chemisorbed nuclei that remained fixed inside the zeolite pores.

The findings of this study help to elucidate the ways in which the acidity and crystal size of zeolites influence the activity and deactivation of the catalyst during glycerol dehydration, highlighting the improvements that could be made by adjusting the size of the crystals and the strength of the zeolite Brønsted acid sites.

\section{Acknowledgements}

This work was supported by the Brazilian agencies $\mathrm{CNPq}$ (project numbers 470094/2013-3, 401679/2013-6 and 473456/2012-5) and FAPESP (project numbers 2010/01449-3, 2013/01328-0, and 2014/20116-6).

\section{References}

[1] B. Katryniok, S. Paul, V. Belliere-Baca, P. Rey, F. Dumeignil, Green Chem. 12 (2010) 2079-2098

[2] B. Katryniok, S. Paul, F. Dumeignil, ACS Catal. 3 (2013) 1819-1834.

[3] B. Katryniok, S. Paul, M. Capron, C. Lancelot, V. Belliere-Baca, P. Rey, F. Dumeignil, Green Chem. 12 (2010) 1922-1925.

[4] Z. Wang, L. Wang, Y. Jiang, M. Hunger, J. Huang, ACS Catal. 4 (2014) 1144-1147.

[5] B.O. Dalla Costa, M.A. Peralta, C.A. Querini, Appl. Catal. A-Gen. 472 (2014) 53-63.

[6] Y.T. Kim, K.D. Jung, E.D. Park, Appl. Catal. B-Environ. 107 (2011) 177-187.

[7] R. Xu, W. Pang, J. Yu, Q. Huo, J. Chen, Chemistry of Zeolites and Related Porous Materials: Synthesis and Structure, John Wiley \& Sons, 2009.

[8] J. Cejka, A. Corma, S. Zones, Zeolites and Catalysis: Synthesis, Reactions and Applications, John Wiley \& Sons, 2010, 2015.

[9] L. Martins, D. Cardoso, Quim. Nova 29 (2006) 358-364.

[10] C.-J. Zhou, C.-J. Huang, W.-G. Zhang, H.-S. Zhai, H.-L. Wu, Z.-S. Chao, Stud. Surf. Sci. Catal. (2007) 527-530.

[11] Ch. Baerlocher, L.B. McCusker, D.H. Olson, Atlas of Zeolite Framework Types, 6th ed., Elsevier, 2007.

[12] Y.T. Kim, K.-D. Jung, E.D. Park, Appl. Catal. A-Gen. 393 (2011) 275-287.

[13] L.G. Possato, R.N. Diniz, T. Garetto, S.H. Pulcinelli, C.V. Santilli, L. Martins, J. Catal. 300 (2013) 102-112.

[14] R. Klik, V. Bosacek, L. Kubelkova, D. Freude, D. Michel, Zeolites 19 (1997) 343-348.

[15] R. Fricke, H. Kosslick, G. Lischke, M. Richter, Chem. Rev. 100 (2000) 2303-2405.

[16] J.C. Groen, T. Bach, U. Ziese, A. Donk, K.P. de Jong, J.A. Moulijn, J. Perez-Ramirez, J. Am. Chem. Soc. 127 (2005) 10792-10793.

[17] W. Song, R.E. Justice, C.A. Jones, V.H. Grassian, S.C. Larsen, Langmuir 20 (2004) 8301-8306.

[18] B.C. Lippens, J.H. de Boer, J. Catal. 4 (1965) 319-323.

[19] J. Jae, G.A. Tompsett, A.J. Foster, K.D. Hammond, S.M. Auerbach, R.F. Lobo, G.W. Huber, J. Catal. 279 (2011) 257-268.

[20] W.M. Haynes, CRC Handbook of Chemistry and Physics, CRC Press, 2014

[21] W. Suprun, M. Lutecki, R. Glaser, H. Papp, J. Mol. Catal. A-Chem. 342-343 (2011) 91-100.

[22] U.V. Mentzel, K.T. Hojholt, M.S. Holm, R. Fehrmann, P. Beato, Appl. Catal. A-Gen. 417 (2012) 290-297.

[23] Y. Furumoto, Y. Harada, N. Tsunoji, A. Takahashi, T. Fujitani, Y. Ide, M. Sadakane, T. Sano, Appl. Catal. A-Gen. 399 (2011) 262-267.

[24] A. Ausavasukhi, T. Sooknoi, Appl. Catal. A-Gen. 361 (2009) 93-98.

[25] S. Mitchell, M. Milina, R. Verel, M. Hernández-Rodríguez, A.B. Pinar, L.B. McCusker, J. Pérez-Ramírez, Chem. Eur. J. (2015) 14156-14164.

[26] L. Martins, T. Bonagamba, E. de Azevedo, P. Bargiela, D. Cardoso, Appl. Catal. A-Gen. 312 (2006) 77-85.

[27] X.S. Zhao, G.O. Lu, J. Phys. Chem. B 102 (1998) 1556-1561.

[28] S.H. Chai, H.P. Wang, Y. Liang, B.Q. Xu, Green Chem. 9 (2007) 1130-1136.

[29] C.J. Jia, Y. Liu, W. Schmidt, A.H. Lu, F. Schuth, J. Catal. 269 (2010) 71-79.

[30] R. Znaiguia, L. Brandhorst, N. Christin, V. Bellière Baca, P. Rey, J.-M.M. Millet, S. Loridant, Microporous Mesoporous Mater. 196 (2014) 97-103.

[31] M.V. Rodrigues, C. Vignatti, T. Garetto, S.H. Pulcinelli, C.V. Santilli, L. Martins, Appl. Catal. A-Gen. 495 (2015) 84-91.

[32] L.G. Possato, W.H. Cassinelli, T. Garetto, S.H. Pulcinelli, C.V. Santilli, L. Martins, Appl. Catal. A-Gen. 492 (2015) 243-251.

[33] M. Guisnet, P. Magnoux, Appl. Catal. 54 (1989) 1-27.

[34] B. Behera, P. Gupta, S.S. Ray, Appl. Catal. A-Gen. 466 (2013) 123-130.

[35] M.A. Dubé, S. Salehpour, Macromol. React. Eng. 8 (2014) 7-28. 